\title{
Enhancing Road Safety Behaviour Using a Psychological and Spiritual Approaches
}

\author{
Mohd Tarmizi Ghous ${ }^{1}$, Kamarudin Ambak ${ }^{1, *}$, Ryan White Hamsaari ${ }^{1}$, and Ahmad \\ Sharifuddin Mustapha ${ }^{2}$ \\ ${ }^{1}$ Smart Driving Research Center, Faculty of Civil and Environmental Engineering, Universiti Tun \\ Hussein Onn Malaysia, 86400 Batu Pahat, Johor, Malaysia \\ ${ }^{2}$ Department of Islamic and Social Science Studies, Faculty of Science, Technology and Human \\ Development, Universiti Tun Hussein Onn Malaysia, 86400 Batu Pahat, Johor, Malaysia
}

\begin{abstract}
Main causes of accident is due to driver itself that is influenced by their bad attitude while driving. Human attitude is closely related to the human psychology. Apart from that, spiritual aspect also influence human attitude. Hence, this study carried out to improve driver safety using a new approach through psychology and spiritual factors. Objectives of this study are to identify then analyze factors of psychological and spiritual that contribute towards safety driving. A self-administered questionnaire were distributed among 256 respondents from various type of background. An analysis descriptive statistics show demographic and experience of respondents. Chi-square analysis showed only education level and traffic summon are significant to safety driving. Furthermore, correlation analysis shows psychological factors has strong linear relationship on attitude of drivers towards safety driving while spiritual factor, the perception of the spiritual and practices, both have a strong relationship to safety driving. Regression analysis demonstrates boths psychological and spiritual factors have strong evidence and significant relationship with safety driving. Thus, it can be identified that spiritual psychological factors encourage drivers to drive more safely and reduce road accidents. Therefore, this study propose useful guidelines to related agencies in order to enhance safety among drivers to be able drive safely on the road.
\end{abstract}

\section{Introduction}

Accidents problem occurred in Malaysia is one of the most important agenda seriously discussed and various methods were carried out to overcome this problem. Accidents that occurred resulted loss of valuable lives, injury and property [1]. Transport system is divided into three main components which are physical environment, vehicles and road users. There have been many improvements that have been carried out to reduce accidents, especially on the physical environment and the vehicle but less improvement in road users itself. In accordance with population growth, the demand for vehicle use and transportation are also

\footnotetext{
* Corresponding author: kanardin@uthm.edu.my
} 
increased and it was undoubtedly resulting more accidents. Behavior of road users is one of the factors contributing majorly in road accidents involving death or injury.

In a nutshell, users fail to implement some important aspects before driving such as not wearing a safety belt, breaking the speed limit, taking drugs or under the influence of alcohol and not wearing a helmet correctly $[2,3,4]$. Human behavior relates to human internal characteristic such as psychological factors. Psychology is the study of human behavior that was made systematically and scientifically. It is a discipline that studies scientifically human or animal behavior, especially thoughts, attitudes, feelings, instincts, potential, intelligence, needs and human responses to stimuli and social environment [5].

In other perspective, spiritual factors also influence human attitude and behavior. In expressing the concept of spiritual or religious from previous study, mention the impact of religious practice would indicate a person can control or push yourself, relieve stress and shows concern about life and death [6]. Moreover, driver bringing spiritual element in the road such as displaying good behavior, patient, do not rush, humble as recommended in the religion can also reduce accidents [7]. In State of Johor was recorded the highest mortality rate compared to other states for 1128 deaths. This state also contributed most accidents case and increased from the previous year's total of 1073 deaths [8].

Therefore, the need for in-depth study to improve road safety through the study of the psychological and spiritual factors approach and recommend appropriate action. This study was conducting surveys for quantitative data regarding the psychological and spiritual to guide people from different backgrounds, age also in employment among car drivers. This study focusing in determine the factors from psychological and spiritual that contributing to safety driving. Hence, data of this study was collected from driver around Batu Pahat, Johor.

\section{Material and methods}

\subsection{Instrument and measurement}

Instrument and measurement of this study used quantitative data by collected data through questionnaire from respondent which is the designation of questionnaire referred to the Driver's Behavior Questionnaire [9, 10] for psychological elements and for spiritual questionnaire design from Religious Orientation Scale (ROS) [11]. Questionnaire consist of demography question relating to the personal notice of respondents such as age, gender, marital status and others. This questionnaire also contents question for individual perception of psychology and spiritual using likert scale 1 to 5. Other part from questionnaire is open ended asked about respondent opinion in enhancing driving safety. Data was analyzed by using Service Package for Science Sosial (SPSS).

\subsection{Sample size and location of study}

Sample size was determined by referring to the number of population in Batu Pahat. Sample size was determined from [12] which is based on the statistics of population in Batu Pahat 2010 of 3,230,44 then obtained the highest number was 384. This study archive 256 of respondent around Batu Pahat which is $67 \%$ from 384 number of respondent. This study was conducted around city of Batu Pahat, Johor. 


\subsection{Analysis tool}

For analysis method, this study uses a static descriptive analysis method for demography to determine the mean score of respondent. To determine the significant between demography to the factor of psychology and spiritual, Chi-Square analysis was used. In order to determine which factor in psychological and spiritual that contributed to the safety driving, Correlation and Multiple Regression were used.

\section{Results and discussions}

\subsection{Descriptive analysis}

Based on finding from 256 respondents, (79\%) 203 are males and the rest $53(21 \%)$ are females. Most of the respondents are by the age of $20-25$ years old with a total of 118 (46\%) respondent and followed by group age of 30 years old and above with a total of $67(26 \%)$ respondents. From 256 respondent, 71 respondents works in private sector. This finding also shows the highest number of respondents have SPM/STPM with (38\%) 96 respondent and second was have Bachelor, Master or PHD with (35\%) 91. Most of the respondents are Muslims and Malay race. As for the driving licences, most of them posseses competent (Class D) licenses. The demographic part also asked respondent about experiences in driving, involved in accident and traffic summons. Result shows respondent in 2- 5 years' experience is the highest with $84(33 \%)$ and $146(57 \%)$ respondent have no experience involved in accident while (53\%) 135 were involved in traffic summons.

Table 1. Respondent Demographic

\begin{tabular}{lcc}
\hline Respondents & Frequency & $\begin{array}{c}\text { Percentage } \\
(\%)\end{array}$ \\
\hline 1. Gender & 203 & 79 \\
Male & 53 & 21 \\
Female & & \\
2. Age & 12 & 5 \\
Below 20 year & 118 & 46 \\
20-25 year & 59 & 23 \\
26-30 year & 67 & 26 \\
30 year above & & \\
3. Profesion & 38 & 15 \\
Self-employed & 33 & 13 \\
Government Sector & 71 & 28 \\
Private Sector & 88 & 34 \\
Student & 26 & 10 \\
Others & & \\
4. Education & 65 & 25 \\
Diploma & 91 & 35 \\
Bachelor/Master/PHD & 96 & 38 \\
SPM/STPM & & \\
5. Religion & 243 & 95 \\
Muslim & 13 & 5 \\
Non- Muslim & & \\
& & \\
\hline
\end{tabular}




\begin{tabular}{lcc}
\hline 7. Licenses & & \\
Competent (Class D) & 207 & 81 \\
Probationary (Class P) & 27 & 11 \\
Learner (Class L) & 5 & 2 \\
No Licenses & 17 & 6 \\
8. Experience & & \\
$\quad$ Less than 2 years & 38 & 14 \\
2-5 years & 84 & 33 \\
6-9 years & 73 & 29 \\
10 years above & 61 & 24 \\
9. Accident Involved & & \\
Yes & 110 & 43 \\
No & 146 & 57 \\
10. Traffic Summon & & \\
Yes & 135 & 53 \\
No & 121 & 47 \\
\hline
\end{tabular}

\subsection{Chi-square analysis}

Table 2 shows the result of chi - square analysis between factor of psychology and spiritual with background of respondent demography towards safety driving. Based on the result, significant $p$ value less than 0.05 indicated to gender and subjected to the traffic summon which is this two variable for psychological was associated to safety driving. However, all variable for spiritual factors had $p$ more than 0.05 shows that there had no associated to safety driving.

Table 2. Chi - Square analysis

\begin{tabular}{lcccccc}
\hline & \multicolumn{3}{c}{ Psychology } & \multicolumn{3}{c}{ Spiritual } \\
& $X^{2}$ & $P$ & Result & $X^{2}$ & $P$ & Result \\
\hline Age and safety driving & 0.023 & 0.880 & $\begin{array}{c}\text { Not } \\
\text { Significant }\end{array}$ & 2.000 & 0.157 & $\begin{array}{c}\text { Not } \\
\text { Significant } \\
\text { Not } \\
\text { Gender and safety driving }\end{array}$ \\
$\begin{array}{lcccccc}\text { Significant } \\
\text { Education and safety driving }\end{array}$ & 0.104 & 0.747 & Significant & 0.537 & 0.464 & $\begin{array}{c}\text { Not } \\
\text { Experience and safety }\end{array}$ \\
$\begin{array}{l}\text { Driving } \\
\text { Summon and safety driving }\end{array}$ & 1.037 & 0.309 & $\begin{array}{c}\text { Not } \\
\text { Significant }\end{array}$ & 2.095 & 0.148 & $\begin{array}{c}\text { Not } \\
\text { Significant } \\
\text { Not }\end{array}$ \\
\hline
\end{tabular}

\subsection{Correlation analysis}

Table 3 shows the result of correlation analysis between psychological factors as variable and safety driving as constant variable. Based on result, psychology factor have a weak positive linear relationship with value $r=0.24$ while variable for driver's behavior have a moderate negative linear relationship with $r=-0.274$ meaning that driver's behavior have significant relationship with safety driving. For other factors variable obtained strong positive linear relationship and significant $p$ value to safety driving. While in spiritual factors, all of independent variable have strong positive linear relationship to dependent variable safety driving as shown in Table 4. 
Table 3. Correlation for Psychological factors towards safety driving

\begin{tabular}{lcccc}
\hline & $\begin{array}{c}\text { Safety } \\
\text { driving }\end{array}$ & $\begin{array}{c}\text { Psychology } \\
\text { factors }\end{array}$ & $\begin{array}{c}\text { Drivers } \\
\text { behavior }\end{array}$ & $\begin{array}{c}\text { Other } \\
\text { factors }\end{array}$ \\
\hline Safety driving & 1 & & & \\
Psychology factors & $0.243^{*}$ & 1 & & \\
Drivers attitude & $-0.274^{* *}$ & $-0.612 * *$ & 1 & \\
Other factors & $0.479^{* *}$ & -0.002 & $-0.549^{* *}$ & 1 \\
\hline
\end{tabular}

* Correlation is significant at the 0.01level (2-tailed)

** Correlation is significant at the 0.05level (2-tailed)

Table 4. Correlation for Spiritual factors towards safety driving

\begin{tabular}{lccc}
\hline & Safety Driving & $\begin{array}{c}\text { Driver's } \\
\text { Perception }\end{array}$ & $\begin{array}{c}\text { Driver's } \\
\text { Practices }\end{array}$ \\
\hline Safety Driving & 1 & & \\
$\begin{array}{l}\text { Driver's } \\
\text { Perception } \\
\begin{array}{l}\text { Driver's } \\
\text { Practices }\end{array}\end{array}$ & $0.542^{* *}$ & 1 & 1 \\
\hline
\end{tabular}

* Correlation is significant at the 0.01level (2-tailed)

** Correlation is significant at the 0.05level (2-tailed)

\subsection{Multiple regression analysis}

Table 5 shows the summarize results of multiple regression psychological factors were performed using SPSS which is R squared of $32 \%$ of variables contribute towards driving safety. While Table 6 shows the results of multiple regression spiritual factors were $\mathrm{R}$ squared of $43 \%$ of variables contribute towards driving safety.

Table 5. Summarize R square for psychological factors

\begin{tabular}{ccccc}
\hline Model & $\mathrm{R}$ & R Square & $\begin{array}{c}\text { Adjusted } \mathrm{R} \\
\text { Square }\end{array}$ & $\begin{array}{c}\text { Std error of the } \\
\text { estimate }\end{array}$ \\
\hline 1 & $0.563^{\mathrm{a}}$ & $0.317^{\mathrm{a}}$ & 0.307 & 0.5676286 \\
\hline
\end{tabular}

Table 6. Summarize R square for spiritual factors

\begin{tabular}{ccccc}
\hline Model & $\mathrm{R}$ & R Square & $\begin{array}{c}\text { Adjusted R } \\
\text { Square }\end{array}$ & $\begin{array}{c}\text { Std error of the } \\
\text { estimate }\end{array}$ \\
\hline 1 & $0.658^{\mathrm{a}}$ & 0.433 & 0.428 & 0.5231901 \\
\hline
\end{tabular}

Table 7 shows that the summary result from variance analysis (ANNOVA) for safety driving as dependent variable to independent variable in psychology and spiritual factors. Based on the result, value of $p=0.000$ obtained shows that there is a significant relationship between safety driving and factor from psychological and spiritual. From this 
result shows that the psychological and spiritual aspect have a strong impact to drivers towards safety driving.

Table 7. Summary of ANNOVA analysis

\begin{tabular}{ccccccc}
\hline & Model & $\begin{array}{c}\text { Sum of } \\
\text { Squares }\end{array}$ & Df & $\begin{array}{c}\text { Mean } \\
\text { Squares }\end{array}$ & f & Sig \\
\hline Psychology & Regression & 31.005 & 3 & 10.352 & 32.128 & 0.000 \\
& Residual & 67.018 & 252 & 0.322 & & \\
& Total & 98.073 & 255 & & & \\
Spiritual & Regression & 43.068 & 2 & 21.534 & 78.670 & 0.000 \\
& Residual & 56.388 & 253 & 0.274 & & \\
& Total & 99.456 & 255 & & & \\
\hline
\end{tabular}

From Table 8 shows the summary result of coefficient multiple regression also where all of factors obtained $p<0.05$ value which is all of factor from psychology and spiritual have strong relationship and affect drivers towards safety driving as dependent variable. Value of $\beta$ obtained from table also shows the factors was affected to another factor and support objectives of this study to determine the factors from psychology and spiritual that contribute to safety driving.

Table 8. Summary of Coefficient Multiple Regression for Psychological and Spiritual factors

\begin{tabular}{|c|c|c|c|c|c|c|}
\hline & \multirow{2}{*}{ Model } & \multicolumn{2}{|c|}{$\begin{array}{l}\text { Unstandard } \\
\text { Coefficient }\end{array}$} & \multirow{2}{*}{$\begin{array}{l}\text { Standard } \\
\text { Coefficient } \\
\text { Beta }\end{array}$} & \multirow[b]{2}{*}{$\mathrm{t}$} & \multirow{2}{*}{ sig } \\
\hline & & $\mathrm{B}$ & $\begin{array}{l}\text { Std. } \\
\text { Error }\end{array}$ & & & \\
\hline \multirow{4}{*}{ Psychology } & Safety Driving & 3.962 & 0.398 & - & 9.946 & 0.000 \\
\hline & $\begin{array}{l}\text { Psychology } \\
\text { factors }\end{array}$ & -0.291 & 0.057 & -0.373 & -5.142 & 0.000 \\
\hline & $\begin{array}{l}\text { Drivers } \\
\text { behavior }\end{array}$ & -0.186 & 0.067 & -0.203 & -2.799 & 0.006 \\
\hline & Other factors & 0.342 & 0.043 & 0.458 & 7.969 & 0.000 \\
\hline \multirow{3}{*}{ Spiritual } & Safety Driving & 1.535 & 0.227 & - & 6.758 & 0.000 \\
\hline & $\begin{array}{l}\text { Driver's } \\
\text { Perception }\end{array}$ & 0.446 & 0.062 & 0.405 & 7.247 & 0.000 \\
\hline & $\begin{array}{l}\text { Driver's } \\
\text { Practices }\end{array}$ & 0.298 & 0.042 & 0.397 & 7.112 & 0.000 \\
\hline
\end{tabular}

\section{Conclusion}

In conclusion, the driving safety is closely associated with the driver itself and then it is the same to previous studies which indicates that the driver itself is the main cause in contributing to accident occurred and it corresponds with the study carried out by [13], which stated that human behavior itself nowadays contributes to accident with a high percentage of almost $80 \%$. Based on the findings, it can be concluded that the needs of education and learning on the psychological and spiritual and same as [14], human behavior is not something that is available since birth but must be learned, honed and developed through experience. Since these factors have strong evidence which is indicating a strong 
relationship as a factor to drive safely thereby avoiding accidents where it would lead to so much loss to many parties, especially to oneself if involving injury or death.

The authors would like to thanks Universiti Tun Hussein Onn Malaysia (UTHM) for funding this study under the Multidisciplinary Research Grant (MDR) Vot U090 and Smart Driving Research Center (SDRC), Faculty of Civil and Environmental Engineering for support and providing facilities to accomplish the study.

\section{References}

[1] T. Rothengatter, T. Elander, Psychological aspects of road user behaviour, Applied Psychology, 2, 8-9 (1997)

[2] International Federation of Red Cross and Red Crescent, Practical Guide on Road Safety, Geneva, (2007)

[3] K. Ambak, I. Rozmi, R. Atiq, S. Foad, Do Malaysian motorcyclists concern to safety helmet usage? A cross-sectional survey, Journal of Applied Sciences, 11(3), 555-560 (2011)

[4] M.B. Ahmed, K. Ambak, A.R.A. Ghani, N.S. Sukor, Helmet usage among adolescents in rural road from the extended theory of planned behaviour, Journal of Applied Sciences 13(1),161-166 (2013)

[5] A. Yahaya, Psikologi Sosial Alam Remaja, PTS Profesional Publishing, Selangor, (2005)

[6] M. Argyle, B.Beit-Hallahmi, The Psychology of Religious Behavior, Belief and Experience, Routledge, London, (1997)

[7] A. Abdullah, Tangani Kemalangan Jalan Raya Melalui Pendekatan Syariat Islam, Pemikir No. 44, Utusan Karya, 125139 (April-June 2006)

[8] Polis Diraja Malaysia, Road Accidents Statistical Reports Malaysia 2012, Cawangan Bukit Aman, Kuala Lumpur, (2012)

[9] J. Reason, A. Manstead, S. Stradling, J. Baxter, K. Campbell, Errors and violations on the roads: A real distinction?. Ergonomics, 33(10-11), 1315-1332 (1990)

[10] N. Rosli, K. Ambak, B.D. Danial, J. Prasetijo, Penerimaan sistem penguatkuasaan automatik (AES) Dalam kalangan pemandu menggunakan model penerimaan teknologi, Jurnal Teknologi, 75(1),1-6 (2015)

[11] G.W. Allport, J.M. Ross, Personal religious orientation and prejudice, Journal of Personality and Social Psychology, 5, 432-443 (1967)

[12] R.V. Krejcie, D.W. Morgan, Determining sample size for research activities, Educational and Psychological Measurement, 30, 607-610 (1970)

[13] R. Lancaster, R. Ward, The Contribution Of Individual Factors To Driving Behavior: Implications For Managing Work-Related Road Safety, Entec UK Limited, (2002)

[14] A.K. Lim, Hubungan Sikap Pengguna dengan Keterlibatan dalam Kemalangan Jalan Raya. Kajian Kes di Negeri Melaka, Master Thesis, Universiti Sains Malaysia, Penang, (2007). 